\title{
Parallel plastic tank experiments with cultures of marine diatoms
}

\author{
U.H. Brockmann ${ }^{1}$, K. Eberlein ${ }^{1}$, G. HentzscheL ${ }^{2}$, H. K. SchöNE ${ }^{3}$, \\ D. SIEBERS ${ }^{4}$, K. WANDSCHNEIDER ${ }^{5} \&$ A. WEBER ${ }^{5}$ \\ ${ }^{1}$ Institut für Organische Chemie und Biochemie, Universität Hamburg; Hamburg, \\ ${ }^{2}$ Abteilung für Mikrobiologie, Institut für Allgemeine Botanik, Universität Hamburg; \\ Hamburg, \\ ${ }^{3}$ Abteilung für Systematik u. Geobotanik, Botanisches Institut, \\ Rbeinisch-Westfälische TH Aachen; Aachen, \\ 4 Biologische Anstalt Helgoland (Zentrale); Hamburg, \\ ${ }^{5}$ Institut für Allgemeine Botanik, Universität Hamburg; \\ Hamburg, Federal Republic of Germany
}

\begin{abstract}
The reproducibility of tank experiments concerning unicellular marine algal development was analyzed by means of parallel experiments with cultures of Thalassiosira rotula and Skeletonema costatum, using large flexible plastic tanks under semi-natural conditions. The tanks (3-4 $\mathrm{m}^{3}, 4-5 \mathrm{~m}$ deep) were exposed in the German Bight at a station in the outer harbour of Helgoland. The water was obtained from the open North Sea in towable tanks; it was filtered (plate filter), enriched with nitrate $\left(20-30 \mu \mathrm{gat} \mathrm{dm}{ }^{-3}\right)$, phosphate $(1.3-2.3$ $\mu$ gat $\mathrm{dm}^{-3}$ ) and silicate (15-23 $\mu$ gat $\mathrm{dm}^{-3}$ ) - nearly natural springtime concentrations in this area - and inoculated with $10^{3}-10^{5}$ cells $\mathrm{dm}^{-3}$. The water was mixed with non-metal stirring equipment. Within 5 days, concentrations of $10^{6}-10^{7}$ cells $\mathrm{dm}^{-3}$ in an exponential grow th phase were obtained. In experiments with $T$. rotula a parallel development was achieved in spite of some contamination by surrounding water. This is the case for nearly all parameters analyzed (nutrient salts, phytoplankton, bacteria, $\mathrm{C}, \mathrm{N}$ and particulate carbohydrates). The heterotrophic bacteria, which were determined by means of the plate method, reached concentrations of up to $10^{6}$ ( $T$. rotula) and $10^{5}$ ( $S$. costatum) CFU $\mathrm{cm}^{-3}$, respectively. They showed a consistent retrograde development at diatom concentrations above a certain level. The crop did not increase again until the diatoms had reached the stationary phase. During exponential growth of $T$. rotula $(G=8.9-11.7 \mathrm{~h})$ a partially synchronous cell division was observed. There were also rhythms with respect to cell size (pervalvar axes) and chain length (number of cells). For the experiments with $S$. costatum ( $G=10-11.4 \mathrm{~h}$ ) diurnal variations of cell size and chain length occurred. The present results indicate acceptable reproducibility of algal development and related phenomena in enclosed water bodies.
\end{abstract}

\section{INTRODUCTION}

One of the most critical aspects of in situ experiments with large tanks is reproducibility. In parallel experiments, phytoplankton, measured as number of cells 
or chlorophyll concentration, has shown strongly divergent (Stepanek \& Zelinka, 1961) as well as coincident (Kemmerer, 1968; McLaren, 1969; Takahashi et al., 1975) development. In experiments with natural plankton populations, development in the tank was similar to that in the surrounding water, in lakes (Kemmerer, 1968; McLaren, 1969) as well as in marine bays (Takahashi et al., 1975).

The experiments were performed in the outer harbour of Helgoland (North Sea). From an investigation on a natural phytoplankton population conducted in 1972 (Brockmann et al., in prep.) two of the numerous diatom species which occurred during the experiment, (Thalassiosira rotula and Skeletonema costatum) were isolated, kept in culture and served for inoculation in 1973 and 1975. Frequent samples were taken from these simplified systems for investigations on the development of plankton and nutrients. In addition, comparative in vitro experiments are planned.

\section{METHODS}

Construction and anchoring of the tanks (1 $\mathrm{m}$ diameter, 4-5 $\mathrm{m}$ depth, 3-4000 $\mathrm{dm}^{3}$ ) has already been published by Brockmann et al. (1974). Natural seawater was pumped from a depth of about $5 \mathrm{~m}$ in an area 7 to 10 nautical miles west of Helgoland with a Vanton Flex-i-liner pump and transported to Helgoland harbour in flexible plastic tanks with a protective covering of Trevira. Here the water was filtered ( $\mathrm{p}<0.05 \mathrm{~atm}$ ) into a $20 \mathrm{~m}^{3}$ floating flexible plastic holding tank, using a plate filter (Seitz, Bad Kreuznach, type 2/1250, with an effective surface of $4 \mathrm{~m}^{2}$ ). After mixing the water was pumped into the experimental tanks. A germfree filtration was avoided in order to preserve the natural bacterial population serving as protection against a one-sided development of particularly favoured contaminants. By means of stirrers, an upwelling current of about $3.5 \mathrm{~cm} \mathrm{sec}^{-1}$ was produced (Brockmann et al., 1974) to insure a continuous mixing of the water in the tank.

After enrichment with nutrients (nitrate, phosphate and silicate; see Table 1) to obtain springtime concentrations of the region (see data given in 'Jahresberichte der Biologischen Anstalt Helgoland', 1967-1973) the tanks were inoculated with monocultures of equal cell numbers of the two diatom species isolated in 1973. The species had been precultured in a medium described by von Stosch \& Drebes (1964) at $15^{\circ} \mathrm{C}$ and $\operatorname{LD} 16: 8$.

Some tanks were additionally inoculated at certain stages with streptomycin resistant mutants of bacterial strains which had previously been isolated from waters near Helgoland. The number of colony forming units (CFU $\mathrm{cm}^{-3}$ ) of heterotrophic bacteria was determined at $12 \mathrm{~h}$ intervals using Marine Agar 2216 (Difco, Detroit, USA). For determination of the CFU of the streptomycin resistant strains, the Marine Agar was cooled to $50^{\circ} \mathrm{C}$ and then mixed with streptomycin sulfate $(50 \mu \mathrm{g}$ $\mathrm{cm}^{-3}$ ). The cultures were started $30-60 \mathrm{~min}$ after sampling.

Samples for nutrient determinations were immediately frozen after filtration with a glass fiber filter (GF/C-Whatman $1.2 \mu \mathrm{m}$ retention ability) and were analyzed 
Marine diatom cultures in plastic tanks

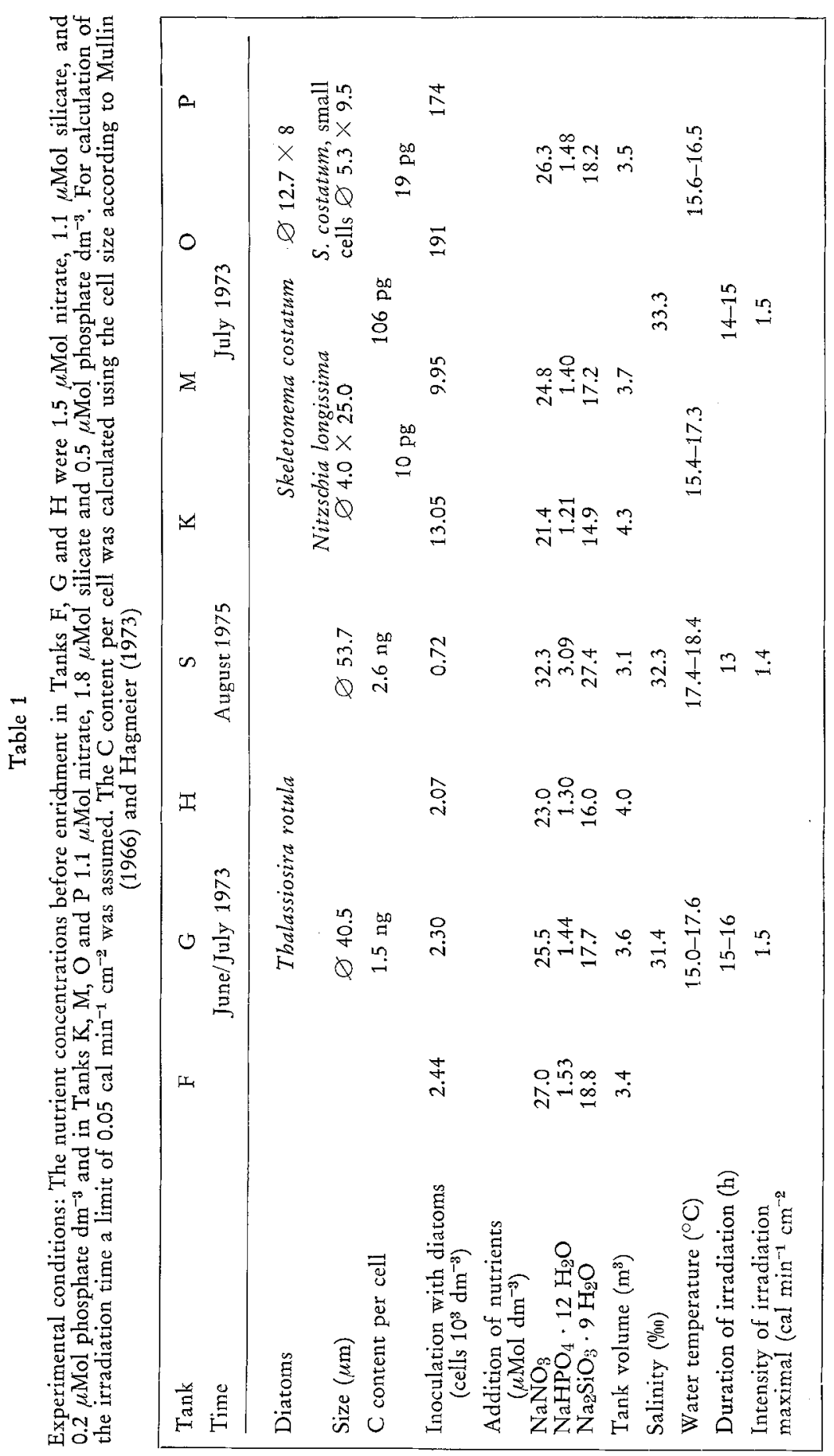


in the course of a few months with a Technicon Autoanalyzer ${ }^{R}$ (Brockmann et al., in prep.). Residues on the glass fiber filters from $150-500 \mathrm{~cm}^{3}$ samples were frozen and dried at $50^{\circ} \mathrm{C}$ before analysis of particulate $\mathrm{C}$ and $\mathrm{N}$ by means of a $\mathrm{CHN}$ Analyzer (F \& M 180).

For spectrophotometric pigment determinations $500 \mathrm{~cm}^{3}$ samples were filtered over cellulose nitrate filters (Sartorius SM 11306) and extracted with $90 \%$ acetone (Strickland \& Parsons, 1968).

For analysis of total particulate glucose residues from $1 \mathrm{dm}^{3}$ water samples filtered over polyamid filter (Sartorius SM 11905) were frozen and stored at $-20^{\circ} \mathrm{C}$. For analysis the samples were hydrolyzed and centrifuged. $100 \mathrm{~mm}^{3}$ of the supernatant were diluted with $900 \mathrm{~mm}^{3}$ of distilled water and, after adding $2 \mathrm{~cm}^{3}$ anthrone solution at $0^{\circ} \mathrm{C}\left(2 \mathrm{~g}\right.$ anthrone: $1 \mathrm{dm}^{3}$ conc. $\left.\mathrm{H}_{2} \mathrm{SO}_{4}\right)$, samples were heated for $10 \mathrm{~min}$ at $100^{\circ} \mathrm{C}$. The extinction was measured at $620 \mathrm{~nm}$, using glucose as standard.

This investigation was carried out by: Mrs. K. Wandschneider (culturing and evaluation of Skeletonema costatum and Thalassiosira rotula in 1975), K. Eberlein (nutrient determinations), M. Gillbricht (evaluation of $S$. costatum cultures), G. Hentzschel (microbiological work), H. Junge (station work), H. Schöne (culturing and evaluation of $T$. rotula in 1973), D. Siebers (determination of particulate glucose equivalents), H. Trageser (station work), A. Weber (pigment determinations), and U. H. Brockmann (coordination).

\section{RESULTS}

Due to the exposed location of the tanks in outer Helgoland harbour, some experiments had to be terminated prematurely because of wave damage. However, experiments with a duration of up to 2 weeks could be carried out, to be discontinued after the stationary growth phase had been reached. In all experiments the inoculated cultures grew exponentially and reached a stationary phase within the planned duration of the experiment.

$$
\text { Tanks F, G, H (Thalassiosirarotula) }
$$

The development in regard to cell numbers showed good agreement in the three experiments with $T$. rotula in 1973 (Fig. 1). The generation time was $G=11.7 \pm$ $0.2 \mathrm{~h}$. The experiment which was conducted 2 years later produced similar results, however with a generation time of $G=8.9 \mathrm{~h}$. Immediately after onset of the stationary phase in Tank $G$, the cell number began to decrease. In Tank H living cells were differentiated microscopically from dead ones. After about 2 days of the stationary phase, the proportion of living cells in the total number of cells gradually diminished.

A diurnal rhythm in the cell division could be recognized in all tanks, with a lag phase between $8.00 \mathrm{~h}$ and $12.00 \mathrm{~h}$ (Fig. 1). This periodicity was also observed for the 
mean chain length and the pervalvar axis (Fig. 2). On the average, the pervalvar axis became shorter in the course of the experiment.

The decrease in the concentrations of the nutrients nitrate, silicate and phosphate was parallel in Tanks F, G, H (Fig. 3). The total utilization amounted to $26 \mu \mathrm{Mol} \mathrm{dm}{ }^{-3}$ for nitrate, $18 \mu \mathrm{Mol} \mathrm{dm}{ }^{-3}$ for silicate and $1.6 \mu \mathrm{Mol} \mathrm{dm}{ }^{-3}$ for phosphate. In all tanks the phosphate concentration reached a first minimum value on the 5 th day, while silicate first reached its minimal concentration on the 6th day and nitrate on the 8 th or 9 th day.

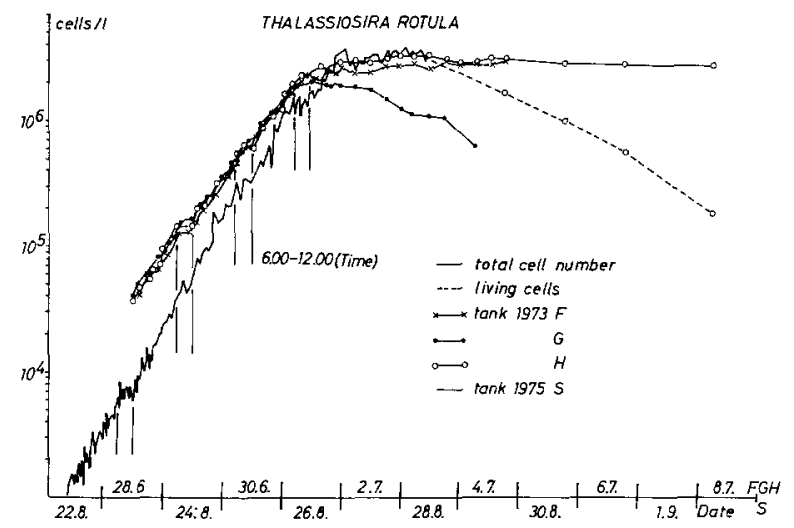

Fig. 1: Number of cells $\mathrm{dm}^{-3}$ of Thalassiosira rotula. The proportion of living cells was only determined for Tank H. In order to emphasize the division rhythm, the most distinct retardation phase was marked

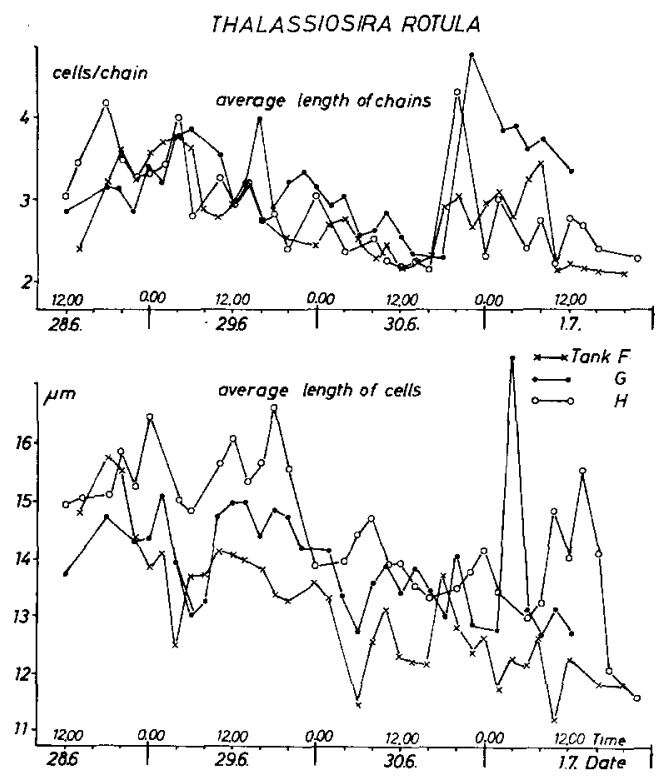

Fig. 2: Average chain length (cell number) and average length of the pervalvar axis of Thalassiosira rotula, Tanks $\mathrm{F}, \mathrm{G}$ and $\mathrm{H}$ (1973) 
The concentrations of chlorophyll $a$ and total carotenoids were in good agreement for Tanks $F, G$ and $H$, however, increasing with a time delay of 6 h between Tanks F, G and H (Fig. 4). The greatest chlorophyll concentrations were reached in Tank $\mathrm{F}$, with $31 \mu \mathrm{g} \mathrm{dm}^{-3}$, while Tank $\mathrm{H}$ with 25.4 and $\mathrm{G}$ with $22.2 \mu \mathrm{g} \mathrm{dm}{ }^{-3}$ lagged behind. The carotenoid concentrations behaved similarly. At the concentration maximum, the ratio of carotenoids/chlorophyll was $2.9: 1$.

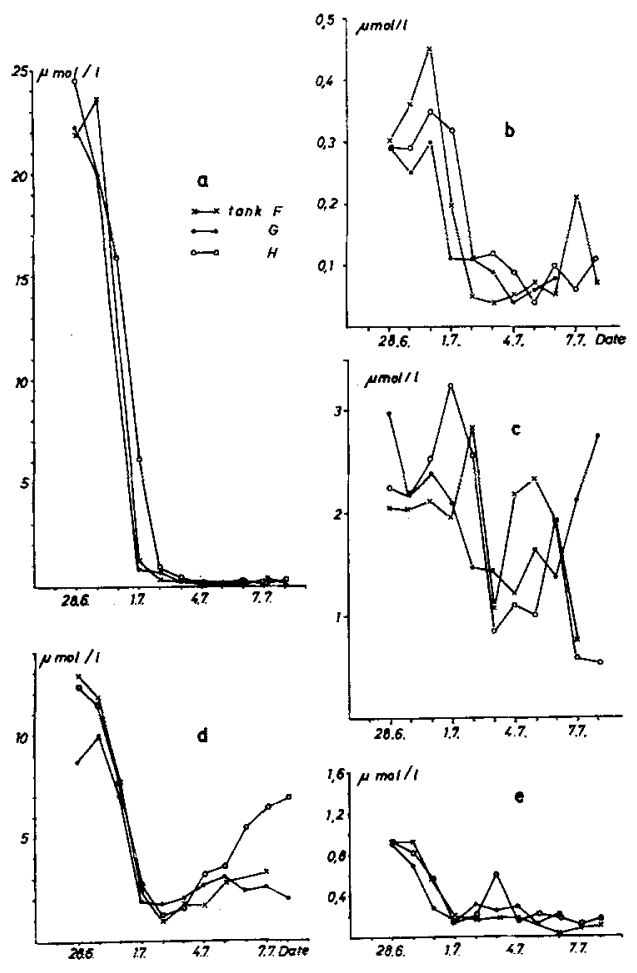

Fig. 3: Average daily concentrations of nitrate (a), nitrite (b), ammonia (c), silicate (d) and phosphate (e), from the second day (June 28) of the experiment on, for Tanks F, G and H with Thalassiosira rotula (1973)

A similar tendency was observed in the concentrations of particulate $\mathrm{C}$ and $\mathrm{N}$ (Fig. 5). A distinct time lapse occurred only in Tank $\mathrm{H}$. The nitrogen concentrations remained constant after the greatest value had been reached, with the exception of Tank G, in which the concentration of particulate nitrogen decreased again soon thereafter. In the decomposition phase the populations exhibited great divergences, showing similar patterns for $\mathrm{C}$ and $\mathrm{N}$ concentrations.

Particulate bound carbohydrates followed a time lag pattern in Tanks F, G and $\mathrm{H}$ similar to $\mathrm{C}, \mathrm{N}$ and pigments (Fig. 6). Here the greatest divergences could also be observed during the decomposition phase, also with about the same time lag. 

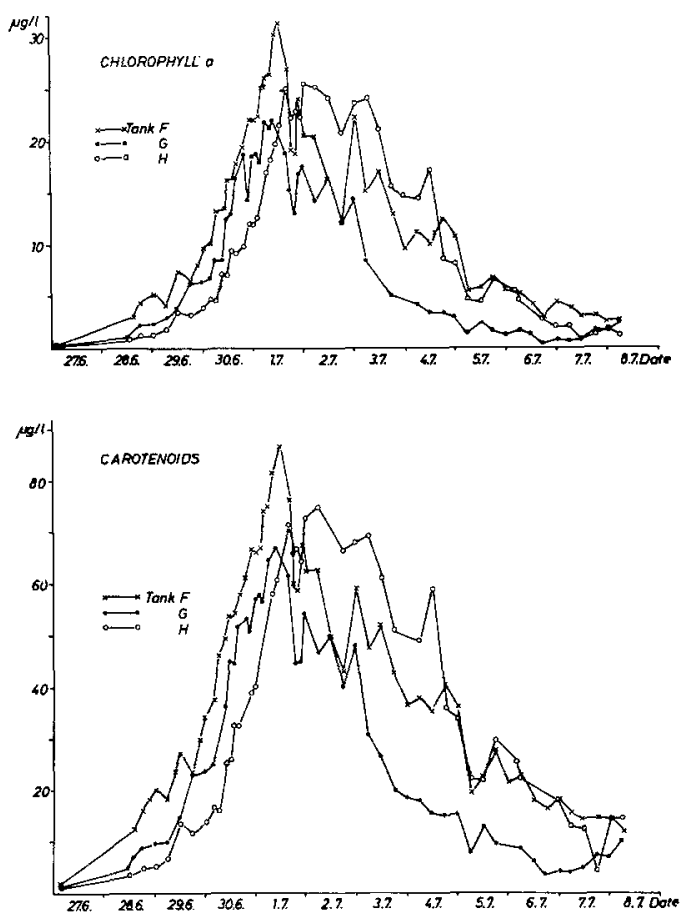

Fig. 4: Chlorophyll $a$ and total carotenoids in $\mu \mathrm{g} \mathrm{dm}^{-3}$ for Tanks F, G and $\mathrm{H}$ inoculated with Thalassiosira rotula (1973)
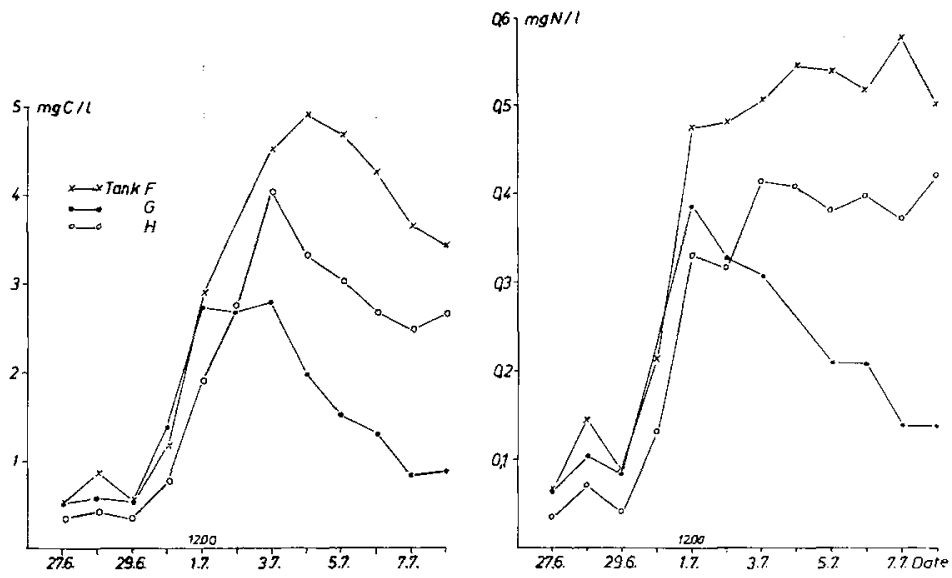

Fig. 5: Particulate carbon and nitrogen concentrations determined with a CHN-Analyzer, as daily average. Tanks F, G and $H$ inoculated with Thalassiosira rotula (1973) 
A nitrogen balance was drawn without consideration of dissolved organic nitrogen compounds for Tanks $F$ and $H$. In Tank $G$ a nitrogen deficit of $17 \mu$ gat $\mathrm{dm}^{-3}$ was found with respect to the initial value.

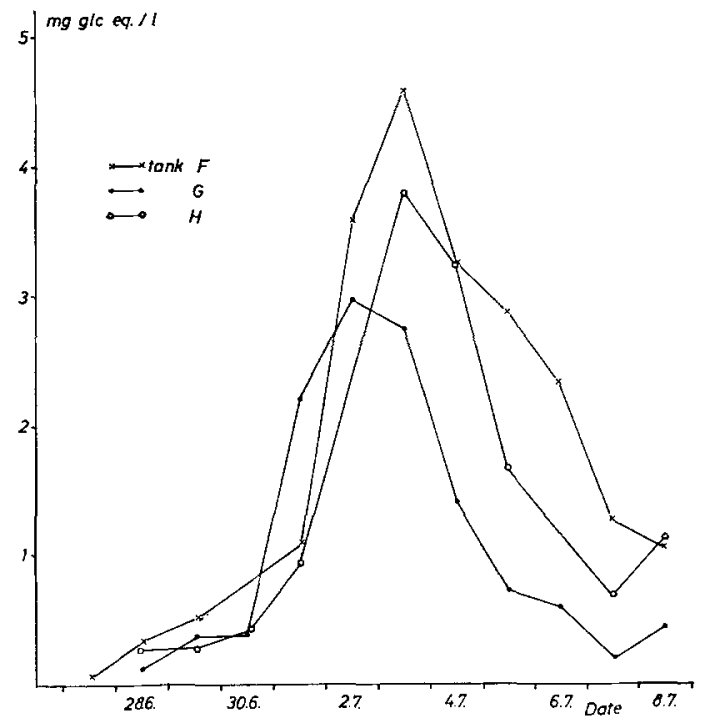

Fig. 6: Average daily particulate carbohydrate concentrations, given as glucose equivalents. Tanks F, G, H with Thalassiosira rotula (1973)

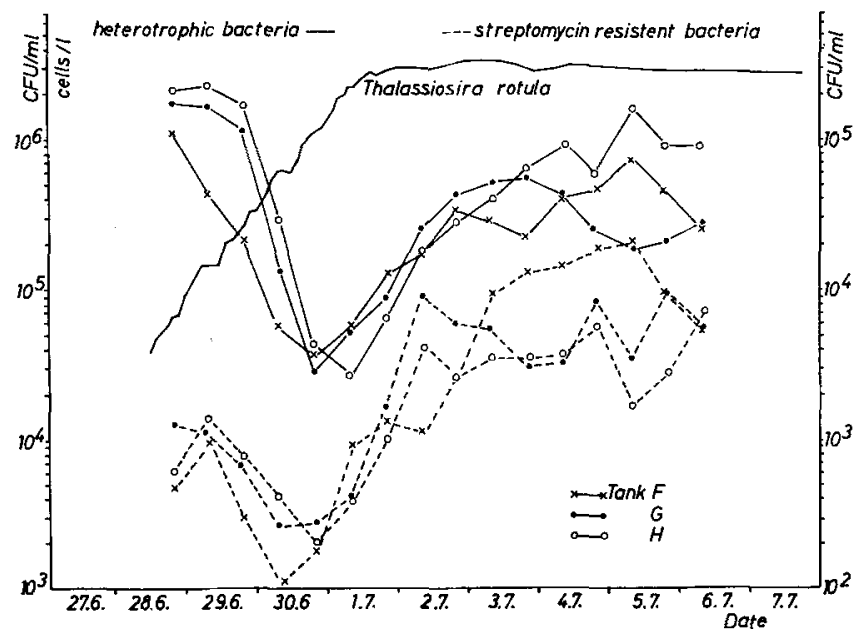

Fig. 7: Development of heterotrophic colony forming bacteria units (CFU). The streptomycin resistant bacteria are presented on a shifted scale. Tank $\mathrm{G}$ was additionally inoculated with streptomycin resistant bacteria on June 30th (1973) 
Heterotrophic bacteria (CFU $\mathrm{cm}^{-3}$ ) showed a parallel development in Tanks F, $\mathrm{G}$ and $\mathrm{H}$ (Fig. 7). During the exponential algal growth phase bacterial numbers decreased and increased again during the stationary phase. This tendency was also observed in Tank S.

\section{Tanks K, M, O, P (Skeletonemacostatum)}

The tank experiments with $S$. costatum also revealed good agreement with respect to cell numbers (Fig. 8). Tanks $\mathrm{O}$ and $\mathrm{P}$ were inoculated with a higher initial cell concentration (Table 1), causing a shift in the time axis.

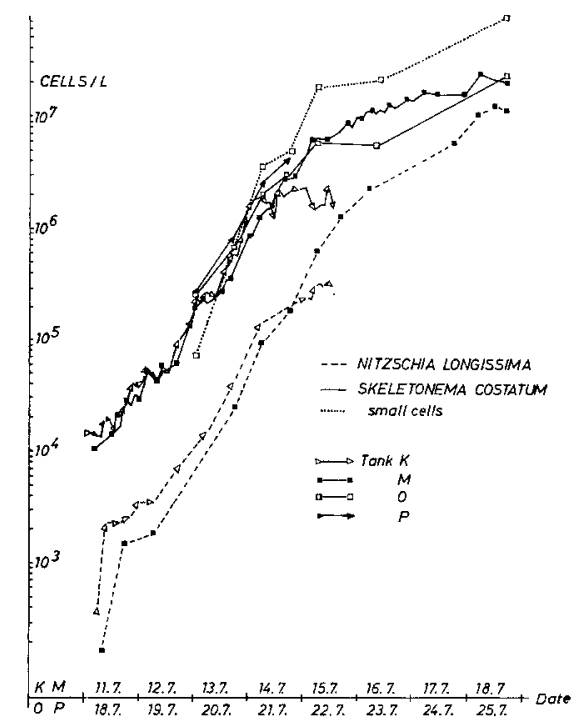

Fig. 8: Logarithms of the cell numbers plotted versus time. Tanks $K, M, O$ and $P$ were inoculated with Skeletonema costatum (13 $\mu \mathrm{m} \varnothing)$. Tanks K and M were contaminated with Nitzscbia longissima; Tank $O$ with a smaller size class of $S$. costatum $(5 \mu \mathrm{m} \varnothing)(1973)$

On the third day trace metals which inhibited cell division (Fig. 8) were added to Tank $\mathrm{P}$. Tank $\mathrm{K}$ had to be given up prematurely due to damage. The experiments with Tanks $\mathrm{O}$ and $\mathrm{M}$ were terminated at about the same time. Tanks $\mathrm{K}$ and $\mathrm{M}$ contained Nitzschia longissima (up to $3 \%$ of the biomass) along with Skeletonema costatum; the development of the two species ran nearly parallel.

Tank $\mathrm{O}$ contained cells of the same size as those in all other tanks ( $\phi 12.7 \mu \mathrm{m})$ as well as smaller ones $(\phi 5.3 \mu \mathrm{m}$ ), which divided more quickly than the larger cells and accounted for up to $25 \%$ of the biomass. Both size classes could be easily distinguished from each other and showed parallel developments. Contamination by other cells, as manifested by a great species diversity, was particularly evident in Tanks $\mathrm{P}$ and $\mathrm{O}$. However, the concentrations of these cells were four orders of magnitude lower than those of Skeletonema costatum. 

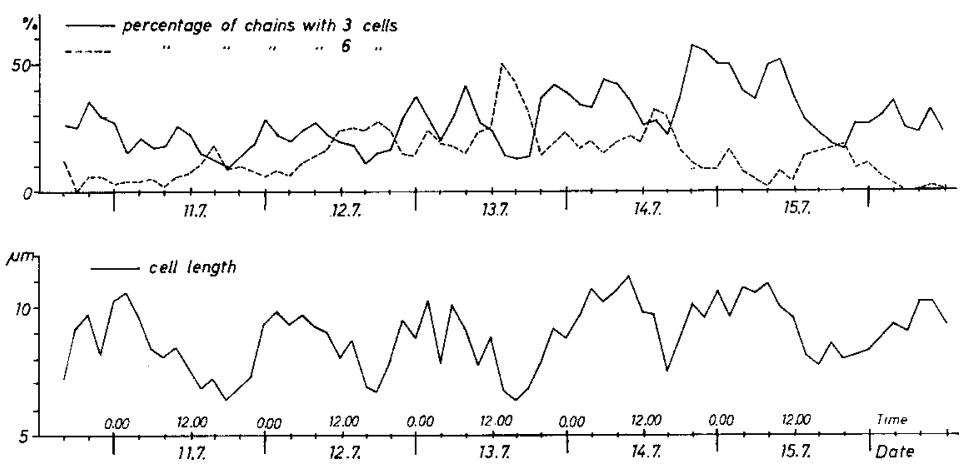

Fig. 9: Length of the cells of Skeletonema costatum (pervalvar axis) and percentage of cell chains with 3 and 6 cells (1973)
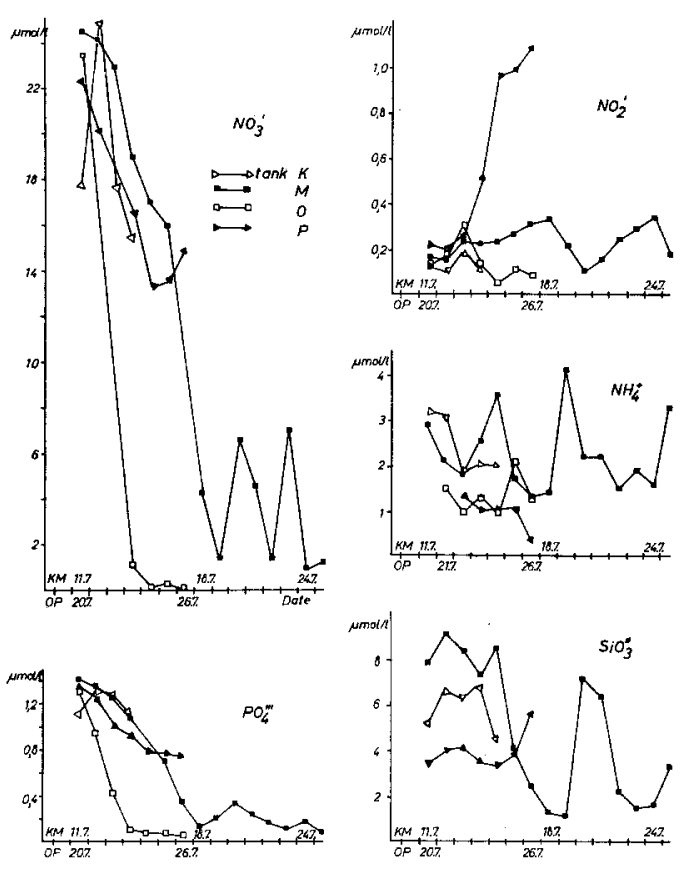

Fig. 10: Daily average concentrations of nutrients for Tanks $\mathrm{K}, \mathrm{M}, \mathrm{O}$ and $\mathrm{P}$ with Skeletonema costatum (1973)

A diurnal periodicity with respect to the length of Skeletonema costatum cells (pervalvar axis) could also be observed in Tank M (Fig. 9). This periodicity was particularly evident in the percentage distribution of the cell chains with 3 and 6 cells/chain. 


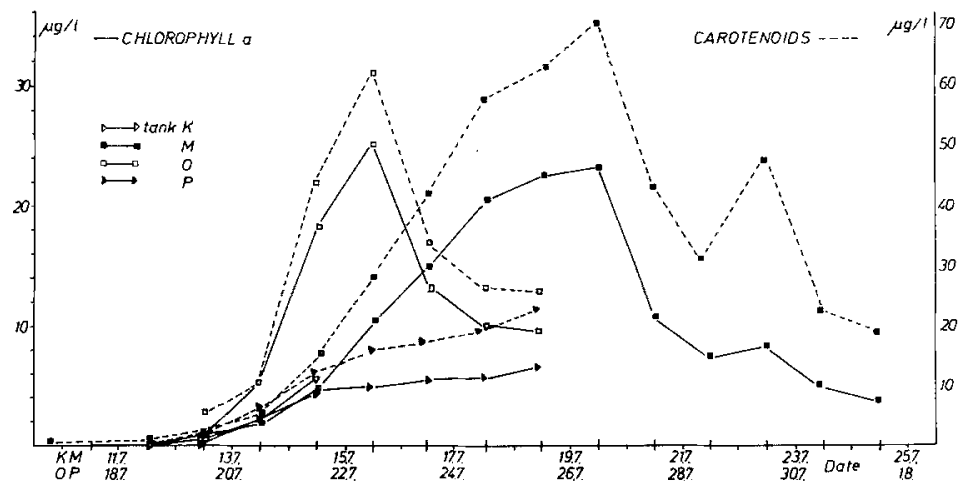

Fig. 11: Chlorophyll a concentrations for Tanks K, M, O and P total carotenoids for Tanks $\mathrm{M}, \mathrm{O}$ and $\mathrm{P}$ (daily averages) (1973)

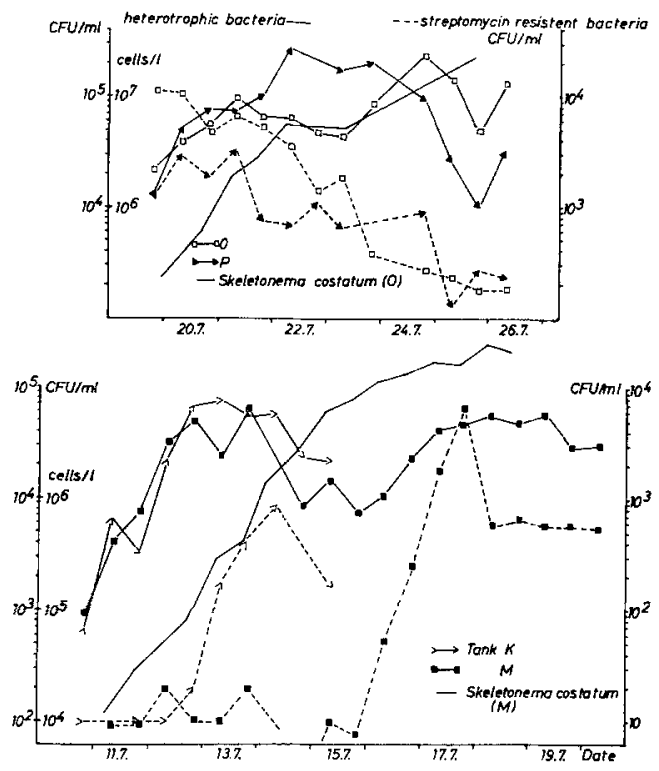

Fig. 12: Along with the number of heterotrophic colony forming bacteria units (CFU) in Tanks $O, P$ and $K, M$, the number of Skeletonema costatum cells in Tanks $M$ and $O$ are present in a shifted scale. Streptomycin resistant bacteria are shifted by one order of magnitude relative to the other heterotrophic bacteria in the presentation (1973)

The development of the nutrients in Tanks $\mathrm{K}, \mathrm{M}$ and $\mathrm{P}$ ran parallel during the short period of comparison for all nutrients, while the nutrients in Tank $\mathrm{O}$ decreased much more rapidly (Fig. 10). In Tank $M$ phosphate reached a minimum first (on the 9 th day), followed by nitrate and silicate. In the stationary phase all nutrients showed a slight increase at the same time, becoming exhausted shortly thereafter. 
The concentration of chlorophyll $a$ and the carotenoids also ran parallel for Tanks K, $M$ and $P$ (Fig. 11). In Tank $O$ the pigments had already reached their maximum concentration on the 5 th day. The ratio of carotenoids to chlorophyll at maximum concentrations was $2.5-3.0: 1$.

The development of heterotrophic bacteria showed good agreement in both experimental series - $\mathrm{K}$ and $\mathrm{M}$ as well as $\mathrm{O}$ and $\mathrm{P}$ (Fig. 12). Tank $\mathrm{M}$ had been inoculated with streptomycin resistant bacteria on July 16th; their concentration however, had already begun to increase before inoculation. Streptomycin resistant bacteria also occurred in Tank $\mathrm{K}$, reproducing parallel to the other heterotrophic bacteria. Shortly after the beginning of the experiment $-12 \mathrm{~h}$ after addition of the Skeletonema costatum cultures - Tanks $\mathrm{O}$ and $\mathrm{P}$ were inoculated with coloured, streptomycin resistant bacteria. These accounted for a large proportion of the CFU at the beginning and continuously decreased thereafter. The quantities of bacteria in Tanks $\mathrm{O}$ and $\mathrm{P}$ differed by one order of magnitude.

\section{DISCUSSION}

The results of the experiments conducted with Thalassiosira rotula demonstrate that a convergent development of diatoms under nearly natural conditions can be obtained. In such experiments with open flexible plastic tanks a slight contamination by organisms from the surrounding environment cannot be ruled out. A parallel development appears to be particularly favoured when the inoculated cells have a short generation time in comparison to other algae introduced into the tanks (for instance by spray contamination). The results indicate that these foreign cells, which are represented by numerous species in some cases, do not play a significant role in the development of biomass.

As related to biomass, this is also true for cells introduced into the tanks at the beginning of the experiment, which was observed for Nitzschia longissima (Tanks $\mathrm{K}$ and M, Fig. 8). These contaminations may have occurred during tank installation under unfavorable weather conditions in the case of experiments $K, M, O$ and $P$. .The filter plates had been previously tested to insure that they were impervious to diatoms.

$$
\text { Thalassiosirarotula (Tanks F, G, H, S) }
$$

The generation time of Thalassiosira rotula amounted to $8.9 \mathrm{~h}$ (Tank S) and $11.7 \mathrm{~h}$ (Tanks F, G and H). In July/August 1972 we obtained a generation time of $\mathrm{G}=10 \mathrm{~h}$ (Brockmann et al., in prep.).

The periodicity in cell divisions of Thalassiosira rotula was observed consistently in all tanks (Fig. 1). Apparently this reflected a diurnal rhythm, since a great number of cells divided after a retardation of cell division between $8.00 \mathrm{~h}$ and $12.00 \mathrm{~h}$. A less marked retardation in cell division was observed between $22.00 \mathrm{~h}$ and $0.00 \mathrm{~h}$, corresponding to a generation time of $G=11.7 \mathrm{~h}$. The cell division phase which 
began after $0.00 \mathrm{~h}$ is also evident in a temporary reduction by more than $10 \%$ in the average pervalvar axis (Fig. 2), which can also be observed after $12.00 \mathrm{~h}$. During the entire experiment a gradual reduction in the pervalvar axis could be observed, decreasing after 6 divisions from 15.2 to $12.2 \mu \mathrm{m}$. The mean chain length also changed in the same rhythm as the cell divisions, since the chains fall apart when the cells begin to divide. These results reveal synchronous divisions for a considerable proportion of cells.

Phosphate was the first nutrient with minimum concentrations in Tanks F, G and $H$ (Fig. 3). Since the algal populations reached the stationary phase simultaneously, phosphate must be regarded as a limiting factor. Along with nitrate, nitrite was presumably also used as nitrogen source, reaching a minimum value at the same time as nitrate. The phosphorous concentration per cell remained constant since July 1 st. This was also valid for nitrogen and silicon (calculated from phosphate respectively silicate decrease), thus preserving an approximately constant ratio of elementary cell composition: $\mathrm{P}: \mathrm{N}: \mathrm{Si}=1: 18: 11$.

The concentrations of $\mathrm{C}, \mathrm{N}$, glucose, chlorophyll $a$ and carotenoids in the particulate matter (Fig. 4, 5 and 6) show good agreement between the individual tanks; however, the developments are more divergent than might have been expected from nearly identical cell numbers in the exponential growth phase (Fig. 1). It is primarily due to the difference in the volumes of the three tanks (Table 1) that the final concentrations of particulate matter were greater in the $15 \%$ smaller Tank $F$ than in Tank $\mathrm{H}$.

The development of Thalassiosira rotula in Tank $\mathrm{G}$ was apparently disturbed after June 30th, since the concentrations of all particulate substances remained below those in the other tanks. It must be questioned, if the inoculation with streptomycin-resistant bacteria on June 30th is a reason for this retardation. Only the development of pigment concentrations (Fig. 4) until July 1st consistently corresponds to the different tank volumes for all three tanks. The differences attained up to $20 \%$ of the maximum values and can hardly be attributed to contamination by Skeletonema costatum, the highest concentrations of which were $3 \cdot 10^{6} \mathrm{dm}^{-3}$, corresponding to $2 \%$ of the biomass of $T$. rotula in Tank $F$.

As has been frequently observed, the average $\mathrm{C} / \mathrm{N}$ weight-ratio shifted in all tanks after the nitrogen sources had been exhausted (from 6.2-6.5 to 8-9.0).

The proportion of particulate carbohydrates in the particulate carbon also increased from 20 to over $40 \%$ (by weight) on the 7th day (July 3rd) (cf. Antia et al., 1963), rapidly decreasing again thereafter, as did the values for the pigments (Fig. 4) and the number of living cells (Fig. 1).

The decrease in particulate carbon can exclusively be explained by the reduction of particulate carbohydrates. From June 29 th to July $3 \mathrm{rd}$ the average particulate carbon concentration per cell amounted to $1.6 \mathrm{ng}$. For an average cell volume of $18.000 \mu \mathrm{m}^{3}$, this corresponds to $1.5 \mathrm{ng} \mathrm{C}$ per cell as calculated from Mullin's specifications (1966).

The nitrogen content per cell, which was calculated from the particulate nitrogen and the decrease in nutrients, was consistent in all tanks and remained approximately $0.18 \mathrm{ng}$ in Tanks $\mathrm{F}$ and $\mathrm{H}$ after the 5 th day (July $1 \mathrm{st}$ ). 
The development of heterotrophic bacteria (Fig. 7) showed a tendency opposite to that of phytoplankton during the exponential growth phase. After a concentration of about $10^{5}$ cells $\mathrm{dm}^{-3}$ had been achieved for Thalassiosira rotula, the growth of the bacteria was inhibited, increasing again shortly before the stationary plankton phase began. A possible explanation may be based on inhibitor substances released by the diatoms. These substances are probably no longer produced during the stagnation of the cell division, but remain partially active, since the bacteria do not again attain their previous concentration.

The strong increase in streptomycin resistant bacteria in all three tanks after the 5 th day indicates a greater specific rate of division relative to the total population. A competitive inhibition caused by a phosphate deficiency, as determined by Rhee (1972) for bacteria and Scenedesmus sp., could not be detected.

Since nitrogen in Tanks $\mathrm{F}$ and $\mathrm{H}$ remained in an equilibrium condition in the particulate form, immediate remineralization processes can be excluded. Antia et al. (1963) could not detect nitrification in a tank with natural phytoplankton even after 75 days of darkness. It can therefore be assumed that particulately bound bacteria were responsible for the utilization of organic matter produced by the phytoplankton, as was also shown by Hollibaugh (1976).

\section{Skeletonema costatum (Tanks K, M, O, P)}

In spite of contamination by Nitzschia longissima and a Skeletonema costatum population of diminished cell size (Table 1), a development of the inoculated $13 \mu \mathrm{m}$ long $S$. costatum was observed, which was consistent in all four tanks during the exponential growth phase (Fig. 8). In a tank experiment in 1972 with natural plankton the simultaneous occurrence of $S$. costatum and $N$. longissima had already been found, suggesting a non-competitive affinity for similar environmental conditions. The intrinsic rate of natural increase ( $r$ ) determined for natural plankton communities including zooplankton of $r=1.5 \pm 0.2$ day $^{-1}$ for $S$. costatum was lower than the cell division rate of $\mu=2.1-2.4 \mathrm{day}^{-1}$ determined here with monocultures. The same was also true for $N$. longissima, which had values of $r=0.9 \pm$ 0.1 day $^{-1}$ and $\mu=2.7$ day $^{-1}$. These differences could be due to the absence of grazing in this experiment, since light and temperature conditions were comparable in 1972 and 1973. The values determined for $S$. costatum are somewhat greater than those obtained from laboratory experiments under comparable conditions: $\mu=2.0 \mathrm{day}^{-1}$ at $17^{\circ} \mathrm{C}$ (Paasche, 1975) and $\mu=2.4$ day $^{-1}$ maximum at $16-26^{\circ} \mathrm{C}$ (Jitts et al., 1964).

Because of differences in biomass, which arose from the influence of foreign cells in Tanks $K, \mathrm{M}, \mathrm{O}$ and $\mathrm{P}$, the nutrient development could only be directly compared in Tanks $K$ and M (Fig. 10). Increasing concentrations of nitrate in Tank $K$ seem to result from incomplete mixing following nutrient addition. In this experiment phosphate also appeared to be the limiting factor, since the phosphate concentration first reached a minium value in Tank $M$.

The concentration variations of the pigments were comparable, due to the dominant role of Skeletonema costatum (Fig. 11). The concentrations of chlorophyll 
a per cell in Tank M of $0.8 \mathrm{pg}$ correspond to values given by Eppley \& Sloan (1966) and Paasche (1973).

The development of heterotrophic bacteria ran parallel in both experiments ( $K$ and $M$ as well as $O$ and $P$ ), although the concentrations in Tanks $O$ and $P$ were greater than in $\mathrm{K}$ and $\mathrm{M}$ (Fig. 12).

After a concentration of about $10^{6}$ cells $\mathrm{dm}^{-3}$ Skeletonema costatum had been reached, a distinct reduction in the quantity of colony-forming units could be observed ( $\mathrm{K}$ and $\mathrm{M}$ ). This however, was only followed by a naturally occurring streptomycin resistant strain in Tank $\mathrm{K}$ after a delay. The growth of the streptomycin resistant strain which was inoculated into Tank $M$ stagnated after a short time. The streptomycin resistant mutants which were inoculated into Tanks $O$ and $P$ at the beginning of the experiment also showed a retrograde development, contrary to the naturally occurring mutants. A retrograde development due to $S$. costatum probably did not take place in Tank $P$ because of the above-mentioned addition of trace metals on July 21 st, which arrested the growth of $S$. costatum.

In this publication, some of the results on the development of two marine diatom species in enclosed water bodies are presented and discussed under particular consideration of reproducibility. Aspects of dynamical interactions will be presented in future communications.

The reproducibility of parallel tank experiments in regard to algal development (cell numbers, cell division rates, chain lengths and size), nutrient utilization, development of heterotrophic bacteria and bacteria-diatom interactions emphasizes the importance of enclosed water bodies for marine ecological research.

Tank experiments therefore constitute a useful link between laboratory experiments, with their controllable but usually unnatural boundary conditions, and field observations, with their complicated hydrodynamic influences. Results obtained from such experiments under nearly natural conditions improve the interpretation of laboratory experiments and field observations.

Acknowledgements. This work was supported by the Sonderforschungsbereich 94, Hamburg, of the Deutsche Forschungsgemeinschaft. We gratefully acknowledge the help of Mr. E. Trube from the Deutscher Seewetterdienst at Helgoland, who measured water temperature, sunshine duration and light intensity (actinograph). The extensive work demanded by the experiment necessitated the responsible assistance of many technicians and students. We would like to express our gratitude to them, as well as to the crews of the research vessels FK "Uthörn" and MB "Ellenbogen" and to many colleagues in the Marine Biological Station on Helgoland. Thanks are due to: G. Kindermann, Mrs. E. Bedker, Miss G. Bistry, Mrs. E. Brennecke, Mrs. S. Euteneuer, Miss S. Grimme, K. D. Hammer, Miss P. Heuer, G. Kattner, Miss B. Kuß, Mrs. J. Kusters, R. Laszig, H. Mielke, T. Minde, Miss M. Müller, D. Pohland, Miss B. Schaab, H. Schimmel, Mrs. A. Schöne, M. Schumacher, K. J. Trahms and Miss H. Wierhake.

\section{LITERATURE CITED}

Antia, N. J., McAllister, C. D., Parsons, T. R., Stephens, K. \& Strickland, J. D. H., 1963. Further measurements of primary production using a large-volume plastic sphere. Limnol. Oceanogr. 8, 166-183. 
Biologische Anstalt Helgoland, 1967. Jahresbericht 1966, 44.

- 1968. Jahresbericht 1967, 75.

- 1969. Jahresbericht 1968, 66.

- 1970. Jahresbericht 1969, 50.

- 1971. Jahresbericht 1970, 52-53.

- 1972. Jahresbericht 1971, 42-43.

- 1973. Jahresbericht 1972, 29.

Brockmann, U. H., Eberlein, K., Junge, H. D., Trageser, H. \& Trahms, K. J., 1974. Einfache Folientanks zur Planktonuntersuchung in situ. Mar. Biol. 24, 163-166.

Eppley, R. W. \& Sloan, P. R., 1966. Growth rates of marine phytoplankton: Correlation with light absorption by cell chlorophyll $a$. Physiologia Pl. 19, 47-59.

Hollibaugh, J. T., 1976. The biological degradation of arginine and glutamic acid in seawater in relation to the growth of phytoplankton. Mar. Biol. 36, 303-312.

Jitts, H. K., McAllister, C. D., Stephens, K. \& Strickland, J. D. H., 1964. The cell division rates of some marine phytoplankters as a function of light and temperature. J. Fish. Res. Bd Can. 21, 139-157.

Kemmerer, A. J., 1968. A method to determine fertilization requirements of a small sport fishing lake. Trans. Am. Fish. Soc. 97, 425-428.

McLaren, I. A., 1969. Primary production and nutrients on Ogac Lake, a landlocked fiord on Baffin Island. J. Fish. Res. Bd Can. 26, 1561-1567.

McLeod, H. C. \& McLeod, G. C., 1961. The physiological ecology of a marine diatom, Skeletonema costatum (Grev.) Cleve. J. mar. Res. 19, 70-87.

Mullin, M. M., Sloan, P. R. \& Eppley, R. W., 1966. Relationship between carbon content, cell volume and area in phytoplankton. Limnol. Oceanogr. 2, 307-311.

Paasche, E., 1973. The influence of cell size on growth rate, silica content, and some other properties of four marine diatom species. Norw. J. Bot. 20, 197-204.

- 1975. The influence of salinity on the growth of some plankton diatoms from brackish water. Norw. J. Bot. 22, 209-215.

Rhee, G. Y., 1972. Competition between an alga and an aquatic bacterium for phosphate. Limnol. Oceanogr. 17, 505-514.

Štěpańek, M. \& Zelinka, M., 1961. Limnological study of the reservoir Sedlice near Zeliv. XVII. The development of phytonannoplankton in silon bags. Sb. vys. Sk. chem.-technol. Praze 5, 275-323.

Stosch, H. A., von \& Drebes, G., 1964. Entwicklungsphysiologische Untersuchungen an zentrischen Diatomeen. IV. Die Planktondiatomee Stephanotyxis turris, ihre Behandlung und Entwicklungsgeschichte. Helgoländer wiss. Meeresunters. 11, 209-257.

Strickland, J. D. H. \& Parsons, T. R., 1968. Practical handbook of seawater analysis. Bull. Fish. Res. Bd Can. 167, 185-206.

Takahashi, M., Thomas, W. H., Seibert, D. L. R., Beeres, J., Koeller, P. \& Parsons, T. R., 1975. The replication of biological events in enclosed water columns. Arch. Hydrobiol. 76, 5-23.

First author's address: U. H. Brockmann

Institut für Organische Chemie und Biochemie

Martin-Luther-King-Platz 6

D-2000 Hamburg 13

Federal Republic of Germany 